\title{
The Impact of Self-Efficacy towards Training Motivation at Kolej Poly-Tech MARA Kuantan, Malaysia
}

\author{
Hafizi Giran ${ }^{1}$, Aziz Amin² \& Bahyah Abdul Halim² \\ ${ }^{1}$ School of Business and Accountancy, Kolej Poly-Tech MARA, Kuantan, Malaysia \\ ${ }^{2}$ School of Business Management and Accountancy, Universiti Sultan Zainal Abidin (UniSZA), Kuala \\ Terengganu, Malaysia \\ Correspondence: Hafizi Giran, School of Business and Accountancy, Kolej Poly-Tech MARA, Kuantan, Km 8 \\ Jalan Gambang, 25150, Malaysia. Tel: 19-513-7459. E-mail: aahmadgiran@gmail.com
}

Received: June 24, 2013 Accepted: July 2, 2014 Online Published: September 29, 2014

doi:10.5539/ass.v10n19p69 URL: http://dx.doi.org/10.5539/ass.v10n19p69

\begin{abstract}
This study aimed to examine the in-depth factors that improve employees' motivation in training program. The critical variable was discussed on training motivation. Random sampling Method used to gather the data from 120 employees at a single point of Kolej Poly-Tech MARA Kuantan. Regression analysis was used for estimating the relationship among variables. The result shows that self-efficacy has a moderate relationship on training motivation. Since data are based on self-reports, common method bias may affect the relationship among the variables. The study only focuses at KPTM Kuantan that was not involved other branches. The paper contributes to both research and practice by providing support to the department heads and the management on ways to increase training motivation among employees. This paper consider few factors that enable to enhance training motivation at KPTM Kuantan
\end{abstract}

Keywords: training motivation, self-efficacy, Kolej Poly-Tech MARA Kuantan

\section{Introduction}

In the $21^{\text {st }}$ century, human capital is paramount for employees due to the contribution factors towards the organization competitive advantage. Generally, the term of human capital can be defined as skill, knowledge and ability that is preserved for a particular organization and difficult to imitate by competitor (Buchholtz, Ribbens, \& Houle, 2003; Hatch \& Dyer, 2004; Kor \& Leblebici, 2005).

There are a lot of organizations believe that human capital plays a crucial role in determining the organizational success hence reflect the value of the labour productivity. Organization with an active human capital, possess skilled worker and considered as income generators for organizations. Thus, Human capital lead to the competitive advantage as it contributes to the value of firms that enhance their performance than competitors (Priem \& Butler, 2001).

In Malaysia, Private higher education is not being exempted in developing human capital. Kolej Poly-Tech MARA (KPTM) is part of them which devote on investing toward human capital through training and development. The primary factor influence human capital in an organization is measured by the degree of investment in education and training. Besides that, it indicates training will be a crucial part in developing of human capital. This is because training becomes a form of investment on human capital for organization that strives to achieve their goals (Brinia \& Efstathiou, 2012).

This paper highlights an issue regarding employee's motivation in this institution. As for now, the implementation of training policy has not created a strong impact on the employee's productivity as a whole. Even though the length of training increased from eight hours to seven days, it is indicated that the failure of fulfilment among employees towards SIRIM criteria occurred. Referring to the ISO 2013 report, one of KPTM branch received non-conformance report (NCR) issued by SIRIM. SIRIM is known as a government institution which is a premier total solution provider in quality and technology innovation. This body have the authority to inspect the institution regularly in order to sustain the quality management system according to ISO 9001:2000. However, result from SIRIM shows that low quality of transfer in training and it will affect the role of human resource department as a training provider. 
According to Davies (2007), outcome measurement in training attended by employees identified with the following questions:

- Has the learning event met its stated objectives?

- Has the trainee transferred the learning to the workplace?

- Can the trainee now meet the requirements of their job?

- Has the trainee been given any required support in the workplace?

Previous study conducted by Society for Training and Development (ASTD) shows that only 77 percent learning reaction occurs followed by 14 percent show the positive attitude behavior for post training and the worst percentage in outcome for training as low low as low as 7 percent (VanBuren, 2001). Training motivation indicate a significant aspect for training results. Colquitt, LePine \& Noe (2000), stress that, trainees will fail to achieve their objective in training program due to low motivation.

Organization has to pay more attention on the motivation of employees as the cost incurred rapidly increased globally. It was surprisingly, the training cost in united states (U.S) base company spent with $\$ 134.39$ billion for all training in 2007 and the cost for each employees was hiking up to \$1,103 per employee in 2007 represent 6 percent increased compare with year of 2006 (Paradise, 2008). As downturn economic occur in 2008 was affected the investment as whole and the figure of training cost declined to $\$ 134.07$ billion (Paradise \& Patel, 2009).

The cost in 2012 ultimately reach to the maximum amount of $\$ 164.2$ billion divided in to several categories that $\$ 100.2$ billion represent 61 percent for internal allocation, the rest amount goes to external services cost $\$ 46$ billion represent 28 percent and tuition reimbursement for 18 billion represent 11 percent (ASTD Industry Report, 2012).

Training motivation is one of determinant for training transfer (Weissbein, Huang, Ford et al, 2010). Previous research also shows that training motivation will result of training transfer among employees (Karl \& Ungsrithong, 1992). Base on the Kirkpatrick theory, training evaluation should be done to ensure training transfer occur. The theory consists of four stages beginning with a reaction, learning, behaviour and lastly result. Kirkpatrick (1994), state that training transfer is measured for training effectiveness.

There is empirical research that shows training motivation play a crucial role to enhance employee actively participate in training programe (Maurer \& Tarulli, 1994; Noe \& Wilk, 1993). It has confirmed that training motivation is important facet need to be studied base on the previous research (e.g. Axtell et al., 1997; Carlson et al., 2000; Cheng, 2000; Guerrero \& Sire, 2001; Tracey et al., 2001).

Without clear explanations on the right factor contribute towards training motivation, it is difficult for human resource manager, head of department and management as a whole to structure year activity in order to develop training motivation among their employees. Therefore this paper aim to seek a solution to ease and acknowledge related bodies on the right factor that influence training motivation in this education business support on the integrative literature interview and data analysis.

\section{Literature Review}

Training motivation is the level of self-confident which drive employees to grab as much knowledge they can in the training program (Teddlie \& Yu, 2007). As a human being, employees require motivation to move up and change to be a skilled person through training and make a contribution for the company's sake. Training primarily, improves the way employees do their work in an efficient way. In order to integrate motivation in training program, concrete solutions are needed to resolve this problem that occur almost at all small medium enterprise (SME) company. Instead of higher apprenticeship fund allocate to develop education/training up to degree level with support coming from around 250 large companies, however, response was not encouraging that only a few small to medium enterprises (SMEs) are involved (Harris, Chisholm, \& Burns, 2013)

Training plays a critical role as a tool to educate people in an organization on knowledge, skill and ability acquired by the employees to perform the job. As training provided by the company, employees should be in a high motivation towards the training attached. Frequent problem occurs where, the employees attending training but they are lacking of motivation. For instance, study conducted by Ford (2009), shows that low training motivation has yield to the low training transfer even though classroom and on-line training methods applied. Consequently, company failed to reach their objective hence affect their productivity (Mackay, 2007). Thus it is a limitation that requires them with extraordinary effort to learn in the training environment and gain what they are supposed to learn. 
Previously, few researchers had called for more research on training motivation (Mathieu, Martineau, \& Tannenbaum, 1993). Nguyen \& Kim, (2013) state in general, it was clear about the influence of training motivation on learning outcomes, but an adequate model that helps understand the antecedents of training motivation has not emerged yet.

Colquitt, LePine \& Noe, (2000) state that employees with low capability and desire to learn succeed in training hence transfer the knowledge instead of employees with high capability and low motivation to learn. Siti Fardaniah, \& Shamsuddin, (2011), state that, Pre-training motivation should not be avoided as it will build the momentum of trainees and sustain the motivation towards the end of a training session. It will drive trainee's self-intention to stay focus until the knowledge required has been fulfilled (Baldwin \& Ford, 1988) and link to the positive effect (Colquitt, LePine, \& Noe, 2000). It was supported by Kieslinger et al. (2009) note that, at the early stage of training, employee's involvement is very important to develop collaborative learning and knowledge building activities.

Previous research studied the extension of training motivation that affects organization. According to Siti Fardaniah \& Shamsuddin (2011), stress that training motivation is an essential criterion for training effectiveness while, research conducted by Cheng and Ho (2001) shows prior research on training motivation affect performance of the training and the outcome as well.

The study also parallel with (Chiaburu \& Tekleab, 2005), stress that training motivation has a positive result with transfer, maintenance and generalization which is called distal outcome. However (Guerrero \& Sire, 2001), note that training motivation relate with training effectiveness including learning and satisfaction and (Cheng, 2000) perceived knowledge and skill transfer. Besides that, one key determinant of training effectiveness is an individual's level of training motivation. As the training effectiveness derives from training motivation, it is concluded that probability of trainees motivation are higher if they experience benefit from training program instead of those who are not (Facteau, 1995).

\subsection{Relationship between Self-efficacy and Training Motivation}

Self-efficacy defined as person belief on their own capabilities to organize and execute towards the action needed to manage prospective situations Bandura (1995). Evidence from past research has shown that self-efficacy has a strong relation between learning and motivation (Pajares, 2002; Zumrah, 2013). Colquitt et al. (2000), state that Self-efficacy has a direct impact with training motivation hence (Tai, 2006) state that if trainee's have a strong determination to learn the skills and knowledge, it reflect the successful of training program.

Employees with higher self-efficacy tend to be more productive and motivated to participate in the training program and willing to learn new knowledge (Tai, 2006). Empirical studies have shown a positive relationship between self-efficacy and training motivation (Colquitt, 2000). Several studies conducted by Tracey (2001) and Judge and Bono (2001) strongly supported the relationship between self-efficacy and training motivation. Besides that, in different study of Self-efficacy found that it has a significant relationship with training performance (Guerrero \& Sire, 2001).

There is a factor drive to training motivation. Tai (2006) in his study, the role played by immediate supervisor is crucial to develop employee's self-efficacy hence improve training motivation that supported with Kirkpatrick theory. Study found, it give an impact towards trainees reaction, learning and transfer motivation.

As the empirical studied discussed, it can be concluded that in training program, trainees with high self-efficacy more likely to be perceived learn as much as possible compared to those who are not (Noe \& Wilk, 1993). Employees with high self-efficacy possess strong believe that they will be able do the task efficiently and effectively. Thus, this group of trainees tend to be motivated and willing to commit any activities embedded in training program. Karl (1993), state that motivation achievement is crucial in order to build self-efficacy in training then improve training motivation.

Besides that, training motivation will result to the encouragement of self-participation on any training provided hence avoid absenteeism on the day of program (Maurer \& Tarulli, 1994), energize the environment of training (Ryman \& Biersner, 1975), and achieve the objective of training (Baldwin \& Ford, 1988). Adult learning theories (Knowles, 1984) state that training work- related should take into consideration to avoid trainees demoralize and less interest to learn.

H1. Self-efficacy has a positive relationship with training motivation 


\section{Methodology}

The research methodology employed in this study was a quantitative method. The reason of administration questionnaire survey was to highlight the variable that influences the training motivation among employees in KPTM Kuantan. The numbers of participant who get involved in this research were 120 of workers only in Kuantan branch. Out of the figure, returned questionnaires with 95 sets represent $79 \%$. All returned questionnaires are usable for this study. Uncollected questionnaires remain 25 sets with $21 \%$. The involvement of staff, 27 male and 68 female were with average of 5 years working experience. They were asked to respond to the questionnaire base on their motivation on the training provided. Random sampling method was employed where the chances of the population being selected and included in the study. Distribution of questionnaires started from Business and Accounting department and followed by Mathematic, Engineering, General Studies, Corporate Unit and Industrial Relation.

Table 1. Survey Response

\begin{tabular}{lcc}
\hline & Total & \% \\
\hline Questionnaires distributed & 120 & 100 \\
Collected questionnaires & 95 & 79 \\
Usable questionnaires & 95 & 100 \\
Uncollected questionnaires & 25 & 21 \\
\hline
\end{tabular}

\subsection{Measurement}

To answer the research questions, questionnaire was used to collect the data that consist of four main parts. The first part was relationship between self-efficacy and training motivation. The second part related with job involvement towards training motivation. The third part involves organizational commitment on training motivation. The last part was designed to gather the demographic information of respondents, composed with six items, age, gender, race, length of service, highest education attainment and marital status

In order to measure the variables, 41 items used in the structured questionnaires that represent for each variable respectively on five point likert scale ranging from $1=$ strongly disagree and $5=$ strongly agree. Administered to eliminate the confusion caused the language barrier, questionnaires consist of dual language with English and Bahasa (Malay language) version.

To assess self-efficacy, ten items from Scholz, Don, Sud, Schwarze (2002) were used. Items read "I will be able to achieve most of the goals that I have set for myself", "Compared to other people, I can do most tasks very well", "I believe I can succeed at almost anything to which I set my mind", and "I will be able to successfully overcome many challenges".

\subsection{Statistical Techniques}

Questionnaires distributed in purpose to examine the relationships between self-efficacy towards training motivation. Several tests were conducted using statistical package for social science (SPSS) version 19.0. Result gathered from data collected from questionnaires.

Quantitative data collected in the form of a questionnaire or survey. In this study, there are three variables that have been identified. Researcher has chosen training motivation as a dependent variable, while independent variables include self-efficacy, organizational commitment and job involvement. Upon collecting the data from the questionnaires, all the information has been coded to enable analysis using Statistical Package for the Social Science (SPSS). Thereafter, a few procedures such as data validation will be carried out for accuracy.

First analysis begins with items accuracy through reliability test. It was conducted an objective to measure the accuracy of each item in the set of questionnaires. According to (Sekaran, 2005) this test is well taken to measure data reliability. In Cronbach's Alpha reliability analysis, the closer Cronbach;s Alpha to 1.0, the higher the internal consistency reliability. (Cronbach's Alpha;Cronbach, 1946). Cronbach measure; order to determine whether there is significant relationship between the independent variables and dependent variable, Pearson Correlation Coefficient analysis were carried out.

Finally, independent-sample t-test was conducted to examine whether there is a statistically significance between independent variable (self-efficacy, job involvement and organizational commitment) with training motivation. 


\section{Data Analysis and Result}

\subsection{Descriptive Analysis}

As analysis conducted, this section will present the result of Pearson Correlation and Linear Regression. Correlation test is conducted to determine the relationship between training motivation as dependent variables and self-efficacy as Independent Variables. Conducting this analysis, enable researcher to know how one variable is related to another, direction and significance of the bivariate relationship of the variables used in the study.

The relationship between employee's self-efficacy was tested against training motivation. The result that is exhibited in table 4.1, indicates that there is significant relationship between the two variables $(r=.357, p<0.05)$. The relationship is significant at the p level of 0.05 . This result suggested that the higher self-efficacy among the staff, the greater training motivation would be. As the result established, it shows that variables has significant relationship with moderate correlation

According to the previous study, there is existence of a relationship between self-efficacy and training motivation. Individuals with substantial self-efficacy will have more training motivation to attend a training program and to learn more (Tai, 2006). It is indicated that there is evidence of relationship between self-efficacy and training motivation (Colquitt, 2000). As empirical study shown the relationship has occured (Tracey, 2001) and supported with model developed by (Judge \& Bono, 2001). The other studies conducted by Tracey (2001), self-efficacy shown to be positively associated with training motivation. The training model by Judge and Bono (2001) indicated that self-efficacy positively influences motivation to learn.

The next analysis which involves multiple regressions was carried out for all variables. Table 4.2 evaluates the impact of self-efficacy, job involvement and organizational commitment on training motivation among employees at KPTM Kuantan. The Multiple Regression Analysis (MRA) treated the dimension of dependent variables and independent variables separately. The reason behind of this process is to determine whether it has a significant impact between independent and dependent variable. Besides that, this analysis also provide the figure of variance and coefficient to determine how precisely self-efficacy effect training motivation. This research explores three independent variables that consist of self-efficacy, organizational commitment and job involvement. The result of multiple regressions is in table.

According to the table, the R-Square value identifies the portion of the variance accounted for by the independent variable is $15.1 \%$ of the variance in the employees training motivation which is accounted for by the self-efficacy, job involvement and organizational commitment. This figure indicates that those three factors explain the influence of employees' motivation by $15.1 \%$. The results also shows that self-efficacy are significantly correlated to employees' training motivation with coefficient alpha $<0.05$.

The beta $(\beta)$ value for self-efficacy $(\beta=.280$ explained the significance of the independent variables on training motivation. Among all, self-efficacy $(\beta=.280)$ is the strongest variables

Table 2. Inter correlation of the major variables

\begin{tabular}{clcccc}
\hline & & 1 & 2 & 3 & 4 \\
\hline 1 & Self-efficacy & - & & \\
2 & Job involvement & $.393^{* *}$ & & \\
3 & Organizational & $.419^{* *}$ & $.532^{* *}$ & $.279^{* *}$ & - \\
4 & Training motivation & $.357^{* *}$ & .197 & $*$ Correlation is significant at the 0.05 level (2-tailed)
\end{tabular}

Table 3. Regression results for the effects of self-efficacy, job involvement, organizational commitment on training motivation

\begin{tabular}{cccc}
\hline Variables & B & t & Sig \\
\hline Self-Efficacy & .280 & 2.560 & .012 \\
Job Involvement & .000 & .000 & 1.000 \\
Organizational Commitment & .178 & 1.508 & .135 \\
Training Motivation & & & \\
\hline
\end{tabular}

R square .151; $\quad$ Adjusted R square .122; $\quad$ F 5.316 
Table 4. Result of analyses and hypotheses

\begin{tabular}{lll}
\hline Hypothesis & p-value & accept or reject \\
\hline H1 Self-efficacy has a positive relationship with training motivation & 0.012 & accepted \\
\hline
\end{tabular}

\section{Conclusion}

The positive coefficient value between independent and dependent variable shows that self-efficacy is an important characteristic that affect the employees' motivation on training program. This explains that, if employees possess high level of self-confidence, they tend to be motivated on training program. The finding was similar to the study done by Tai (2004) stress that towards some extent, training framing will become a factor for employees efficacy in training. In order to increase self-efficacy, Supervisor plays critical part to influence subordinate on training given. Colquitt et al, (2000) note the important role played by supervisor for employees self-efficacy required to be done in pre-training for instance of holding briefing session is seen improve training motivation. Pre-training such as briefing session should be conducted as it will reflect the training session as a whole. Quiñones (1995) posited that pre-training contextual factors such as framing would enhance trainees' abilities to be trained (e.g. self-efficacy, training motivation). Some empirical studies have also shown that pre-information brings trainees more self-efficacy and training motivation. Hicks and Klimoski (1987) state that training motivation development will be depend on the action taken from supervisor that perceived training as important with providing right training information at pre-training level

All the tests shown, self-efficacy give the most impact to employee's training motivation. The finding was parallel to the study conducted by Tai, (2006) which stressed Training motivation also derived from employee's self-efficacy, in regard to whether one can make judgments concerning the ability to successfully learn knowledge and skills. He also stated that individuals with substantial self-efficacy will have more training motivation to attend a training program and to learn more. Machin and Fogarty (2003) found that pre-training self-efficacy predicted post-training self-efficacy and trainee's level of learning during training. This study is aimed to highlight the role and importance of self-efficacy, organizational commitment and job involvement in the training motivation theory. As proposed framework has been tested it indicate on how motivation reflect training effectiveness.

Training motivation become a huge issues and research has been focus on the various facet that affect its relationship. It is provide concrete feedback to the head of department, trainers and managers. This study found that self-efficacy had a great influence on training motivation compare with other variable proposed in the early discussion. In other words this finding was consistence with the previous result conducted by (Tai, 2006, Colquitt, 2000, Tracey 2001). The limitation for this study was data are based on self-reports, common method bias may affect the relationship among the variables which are difficult to control. The study also only focus on one branch of KPTM located in Kuantan and question would arise for the data gather in this study.

As this study provide only a small portion of the training motivation in KPTM Kuantan. Future research should be considered the nine branches of KPTM SDN BHD and the comparison data from cross branches will be used to produce concrete solution on the factors to devote in. Additional numbers of facets in this study should be added to broad the scope of study for instance work environment as peer support, supervisor support, instrumentality and learner readiness that constituent on training motivation as highlighted by (Bhatti, Battour, Sundram et. al. 2013). The extension of the motivation is needed as many study focus on training transfer that involves both the generalization and the maintenance of skills acquired on the job (Chang, 2013).

\section{References}

ASTD. (2012). State of the industry. Retrieved May 28, 2014, http://www.astd.org/Professional-Resources/ State-of-the-Industry-Report

Axtell, C. M., Maitlis, S., \& Yearta, S. K. (1997). Prediction immediate and longer-term transfer of training. Personnel Review, 26, 201-213. http://dx.doi.org/10.1108/00483489710161413

Baldwin, T., \& Ford, J. (1988), Transfer of training: A review and directions for future research. Personnel Psychology, 41, 63-75. http://dx.doi.org/10.1111/j.1744-6570.1988.tb00632.x

Bandura, A. (1977). Social Learning Theory. Englewood Cliffs, NJ: Prentice Hall.

Bandura, A. (1995). Self-Efficacy in Changing Societies. Cambridge University Press.

Bhatti, M. A., Battour, M. M., Sundram, V. P. K., \& Othman, A. A. (2013). Transfer of training: Does it truly happen?: An examination of support, instrumentality, retention and learner readiness on the transfer 
motivation and transfer of training. Journal of Training and Development, 37, 273-297.

Brinia, V., \& Efstathiou, M. (2012). Evaluation of factors affecting training transfer on safety in the workplace: A case study in a big factory in Greece. Industrial and Commercial Training, 44, 223-231.

Buchholtz, A. K., Ribbens, B. A., \& Houle, I. T. (2000). The role of human capital in post-acquisition CEO departure. Academy of Management Journal, 46, 506-514.

Carlson, D. S., Bozeman, D. P., Kacmar, K. M., Wright, P. M., \& McMahan, G. C. (2000). Training motivation in organizations: an analysis of individual-level antecedents. Journal of Managerial Issues, 7, 271-287

Chang, H. (2013). Training transfer in the Taiwanese hotel industry: Factors and outcome. Social Behaviour and Personality, 41, 761-776. http://dx.doi.org/10.2224/sbp.2013.41.5.761

Cheng, E., \& Ho, D., C., K. (2001). The influence of job and career attitudes on learning motivation and transfer. Career Development International, 6, 20-27. http://dx.doi.org/10.1108/13620430110381007

Cheng, Ho. (2001). A review of transfer of training studies in the past decade. Personnel Review, 30, 102-118.

Cheng, W. L. (2000). Test of the MBA knowledge and skills transfer. International Journal of Human Resource Management, 11, 837-852. http://dx.doi.org/10.1080/09585190050075150

Chiaburu, D. S. \& Tekleab, A. G. (2005). Individual and contextual influences on multiple dimensions of training effectiveness. Journal of European Industrial Training, 29, 604-626.

Colquitt, J. A., LePine, J. A., \& Noe, R. A. (2000). Toward an imaginative theory of training motivation: A meta-analytic path analysis of 20 years of research. Journal of Applied Psychology, 85, 678-707.

Davies, E. (2007). Training Manager's Desktop Guide (2nd ed.). United Kingdom: Thorogood.

Facteau, J. D., Dobbins, G. H., Russell, J. E. A., Ladd, R. T., \& Kudisch, J. D. (1995). The influence of general perceptions of the training environment on pretraining motivation and perceived training transfer. Journal of Management, 21, 1-25. http://dx.doi.org/10.1016/0149-2063(95)90031-4

Ford, J. K., \& Weissbein, D. N. (1997). Transfer of training: An updated review and analysis. Performance Improvement Quarterly, 10, 22-41. http://dx.doi.org/10.1111/j.1937-8327.1997.tb00047.x

Ford, L. (2009). Improving training transfer. Journal of Industrial and Commercial Training, 4, 6-92.

Guerrero, S., \& Sire, s., (2001). Motivation to train from the workers' perspective: Example of French companies. International Journal of Human Resource Management, 12, 988-1004.

Harris, M., Chisholm, C., \& Burns, G. (2013). Using the Knowledge Transfer Partnership approach in undergraduate education and practice-based training to encourage employer engagement. Education \& Training, 55, 174-190. http://dx.doi.org/10.1108/00400911311304814

Hicks, W. D., \& Klimoski, R. J. (1987). Entry into training programs and its effects on training outcomes: A field experiment. Academy of Management Journal, 30, 542-552. http://dx.doi.org/10.2307/256013

Judge, T. A., \& Bono, J. E. (2001). Relationship of core self-evaluation traits--self-esteem, generalized self-efficacy, locus of control, and emotional stability--with job satisfaction and job performance: A meta-analysis. Journal of Applied Psychology, 86, 80-92. http://dx.doi.org/10.1037/0021-9010.86.1.80

Karl, K. A. (1993). The impact of feedback and self-efficacy on performance in training. Journal of Organizational Behavior, 14, 379-394. http://dx.doi.org/10.1002/job.4030140409

Karl, K. A., \& Ungsrithong, D. (1992). Effects of optimistic versus realistic previews of training programs on self-reported transfer of training. Human Resource Development Quarterly, 3, 373-384.

Keislinger. (2009). A Participatory Design Approach for the Support of Collaborative Learning and Knowledge Building in Networked Organizations. International Journal of Automation and Computing, 2, 34-38.

Kirkpatrick, D. L. (1994). Evaluation of training. San Francisco: Berrett-Koehler. Kozlowski,

Knowles, M. (1984). The adult learner: A neglected species (3rd ed.). Houston, TX: Gulf Publishing Company.

KPTM History. Retrieved January 20, 2012, from http://www.kptm.edu.my/

Machin, M. A., \& Fogarty, G. J. (2003). Assessing the antecedents of transfer intentions in a training context. International Journal of Training and Development, 8, 36-222.

Mackay, R. (2007). Fit for which purpose. Training and Management Methods, 21, 8-333.

Mathieu, J. E., Martineau J. W., \& Tannenbaum, S. I. (1993). Individual and situational influences on the 
development of self-efficacy: Implications for training effectiveness. Personal Psychology, 46,125-147.

Maurer, T. J., \& Tarulli, B. A. (1994). Investigation of perceived environment, perceived outcome, and person variables in relationship to voluntary development activity by employees. Journal of Applied Psychology, 79, 3-14. http://dx.doi.org/10.1037/0021-9010.79.1.3

Nguyen, K., \& Kim, K. (2013). The Impact of Situational Factors on Pre-Training Motivation. Journal of Leadership, 10, 109-121.

Noe, R. A. (1986). Trainees' attribute and attitudes: Neglected influences on training effectiveness. Academy of management Review, 11,736-749.

Noe, R. A., \& Schmitt, N. (1986). The influence of trainee attitudes on training effectiveness: Test of a model. Personnel Psychology, 39, 497-523. http://dx.doi.org/10.1111/j.1744-6570.1986.tb00950.x

Noe, R. A., \& Wilk, S. L. (1993). Investigation of the factors that influence employees' participation in development activities. Journal of Applied Psychology, 78, 291-302.

Pajares. (2002). Overview of social cognitive theory and of self-efficacy. Retrieved from http://www.emory.edu/EDUCATION/mfp/eff.html

Paradise, A. (2008). 2008 State of the Industry Report, American Society for Training and Development. Alexandria, VA.

Paradise, A., \& Patel, L. (2009). 2009 State of the Industry Report, American Society for Training and Development. Alexandria, VA.

Porter, L. W., Steers, R. M., Mowday, R. T., \& Boulian, P. V. (1974). Organizational commitment, job satisfaction, and turnover among psychiatric technicians. Journal of Applied Psychology, 59, 603-609.

Priem, R. L., \& Butler, J. E. (2001). Is the resource-based "view" a useful perspective for strategic management research? The Academy of Management Review, 26, 22-40. http://dx.doi.org/10.5465/AMR.2001.4011928

Quiñones, M. A. (1997). Contextual influences: On training effectiveness. In Quiñones, M. A., \& Ehrenstein, A. (Eds), Training for a Rapidly Changing Workplace: Applications of Psychological Research, American Psychological Association (pp. 99-177). Washington, D C.

Ryman, D. H, \& Biesner, R. J. (1975). Attitudes predictive of diving success. Personnel Psychology, 28, 181-189. http://dx.doi.org/10.1111/j.1744-6570.1975.tb01379.x

Scholz, U., Gutiérrez-Doña, B., Sud, S., \& Schwarzer, R. (2002). Is general self-efficacy a universal construct? Psychometric findings from 25 countries. European Journal of Psychological Assessment, 18, 242-251.

Schunk, D. H. (1983). Developing children's self-efficacy and skills: The roles of social comparative information and goal setting. Contemporary Education Psychology, 8, 76-86.

Sekaran. (2003). Research methods for business. India: Library of congree-in publication data.

Siti F. A. A., \& Shamsuddin, A. (2011). Stimulating training motivation using the right training characteristic. Industrial and Commercial Training, 43, 54.

Tai, W. T. (2006). Effects of training framing, general self-efficacy and training motivation on trainees' training effectiveness. Personnel Review, 35, 51-65. http://dx.doi.org/10.1108/00483480610636786

Tracey, J. B., Hinkin, T. R., Tannenbaum, S., \& Mathieu, J. E. (2001). The influence of individual characteristics and the work environment on varying levels of training outcomes. Human Resource Development Quarterly, 12(1), 5-23. http://dx.doi.org/10.1002/1532-1096(200101/02)12:1<5::AID-HRDQ2>3.0.CO;2-J

VanBuren, M. E. (2001). The 2001 ASTD State of the Industry Report (Alexandria, VA: ASTD).

Weissbein, D., Huang, J., Ford, J., \& et al. (2010). Influencing Learning States to Enhance Trainee Motivation and Improve Training Transfer, 26, 423-435.

Zumrah, A. (2013). Is job satisfaction enhancing learning-training transfer relationship? Journal of Workplace Learning, 25, 543-555. http://dx.doi.org/10.1108/JWL-02-2013-0005

\section{Copyrights}

Copyright for this article is retained by the author(s), with first publication rights granted to the journal.

This is an open-access article distributed under the terms and conditions of the Creative Commons Attribution license (http://creativecommons.org/licenses/by/3.0/). 